\title{
Antibiotic Sensitivity of Some Phytopathogen Bacteria of Genus Pseudomonas Isolated from Fruit Trees of Azerbaijan
}

\author{
Kh.G. Ganbarov ${ }^{1}$, N.A. Agayeva $^{2}$, F.T. Valiyeva ${ }^{1}$, S.M. Shafiyeva ${ }^{1}$ \\ ${ }^{1}$ Department of Microbiology, Baku State University, Baku-AZ1148 \\ ${ }^{2}$ Department of Microbiology and Immunology, Azerbaijan Medical University, Baku, Azerbaijan \\ *Corresponding Author: Kh.G. Ganbarov, Department of Microbiology, Baku State University, Baku- \\ AZ1148
}

\begin{abstract}
Two hundred and seventy five (275) samples were taken from the plants of pear, blackberry, cherry, mandarin, walnuts and grape grown in Azerbaijan and 142 bacterial strains belonging to the genus Pseudomonas were isolated. All bacterial strains showed hypersensitivity against antibiotics amoxicillin, ampicillin and cefazolinom and no resistant strain was noticed against these antibiotics. All the strains of Ps. cerasi, Ps. citri, Ps. piri, Ps. rubri and Ps. vitivorum showed hypersensitivity against antibiotics ceftazidime, cefazolinum and moxifloxacin and no full-resistant strain was detected against these antibiotics. The strains of Pseudomonas rubri and Ps. vitivorum demonstrated hypersensitivity against ceftriaxone and amikacine, respectively, with no resistant strain against these antibiotics. Pseudomonas cereasi and Ps. citri strains showed high resistance against cefoxitin antibiotics, while Ps. juglandis strains depicted resistence against cefuroxime antibiotics, Ps. rubri strains against azithromycin antibiotics.
\end{abstract}

Keywords: Antibiotics, phytopathogen bacteria, Pseudomonas, sensitivity

\section{INTRODUCTION}

At present about 300 bacterial species cause plants diseases [3]. These bacteria are mainly belong to the species of Agrobacterium, Bacillus, Corynebacterium, Erwinia, Mycobacterium, Pectobacterium, Pseudomonas and Xanthomonas [7,10].

When phytopathogen bacteria infect plant tissue, firstly they degrade intercellular matter (pectin), as a result, of which, the infected tissue softens and rots. Such bacterial rot is usually observed in a bulband root-crops and plant stem. Rotting plant body is exposed to the attack of other bacteria and fungi that stimulate rot $[5,7]$.

The genus Pseudomonas comprizes of the most damaging species of bacteria in plants. More than 50 species of this genus are known to induce various diseases. However, some species specifically cause the diseases in some specific plants. To develop an effective management strategy againstsuch diseases, it is essential to evaluate the effects of antibiotics against a specific pathogen both under in vitro and in vivo conditions $[6,11]$.

Antibiotic sensitivity of phytopatogenic bacteria Pseudomonas beticola, Ps.campestris, Ps. carotue, Ps. holei, Ps. maculicolum, Ps. solanacearum, Ps. tumefaciens and Ps. vesiatonia isolated from maize, beetroot, cabbage, potatoes, tomato and carrot in Azerbaijan [8,9].

The present investigation was aimed to study the antibiotic sensitivity of genus Pseudomonas isolated from the plants in Azerbaijan.

\section{Materials AND Methods}

A total of 250 samples have been taken from the diseased plants of pear, blackberry, cherry, mandarin, walnuts, grape from different regions (Absheron, Astara, Balakan, Gabala, Guba, Gusar, Goychay, Ismailli, Lankaran and Khachmas districts) and 142 strains isolated in pure form during the years of 2014-2016 in the territory of Azerbaijan. Leaves and fruits of plant were collected in sterile packets. At each time of collection, precaution was taken to minimize cross contamination of samples. In order to isolate bacteria and produce pure cultures synthetic nutrient-agar medium mixed with yeast 
extract was used [9]. Medium was prepared by dissolving glucose-20,0 g, pepton-3,0 g, yeast extract$3,0 \mathrm{~g}, \mathrm{p}$ - aminobensoic acid- $0,05 \mathrm{~g}, \mathrm{NaCl}-0.3 \mathrm{~g}$, ağar-20 g into 11 of distilled water. The snips $(1,5-2,0$ sm) were taken from plant samples, put on surface of solid medium in Petri-dish and incubated at $35^{\circ} \mathrm{C}$. Derived cultures were kept in a fridge at $4^{0} \mathrm{C}$ till use.

The identification of bacterial strains was done as per to Bergey's manual of systematic Bacteriology [2] on the basis of morphology ( Gram's staining was performed to determine the size, shape, arrangement and Gram reaction of the izolates), physiological (growth at diferent temperature and at $4 \% \mathrm{NaCl}$ ), biochemical signs (Oxidative-Fermentative test, Nitrate Reduction test, Citrate Utilization test, Urease test, Sucrose fermentation test, Triple Sugar Iodine test, Mannitol Fermentation test, Gelatine Hydrolysis) were done [4].

The sensitivity of the bacteria strains against a new class of antibiotics under in vitro conditions was studied by standard agar disk-diffusion method [1].

For this, the standard (ready) disks ( Liofilchem, Roseto dağlı Abeuzzi, Italian) with absorbed antibiotics of amoxcillin, ampicillin, azithromycin, moxifloxacin, and cefotaxime, ceftazidime, cefriaxone, cefuroxime, cefazolinom, cefoxitin, ciprofloxacin cefalexinom have been used.

The $10 \mathrm{mkl}$ of 0,5 Mac-Farland suspension of the fresh $(24 \mathrm{~h})$ bacterial culture was smeared on the surface of nutrient agar and kept for $30 \mathrm{~min}$ in a thermostat. Then the standart disks with corresponding antibiotics were put on the surface of nutrient ağar ( in Petri plates) and incubated for $24-48 \mathrm{~h}$ at $35^{\circ} \mathrm{C}$. An intact transparent zone around the disk considered as the full sensitivity to antibiotics; while the variant at the end of some colonies in transparent zone was taken as middle sensitivity.

\section{RESULTS AND DISCUSSION}

One hundred and forty two bacterial strains belonging to genus Pseudomonas were isolated from 275 plant samples. Of these 32 strains from pear tree were identified as Ps. piri, 26 isolates from blackberry as Ps. rubri, 20 isolates from cherry as Ps. cerasi, 39 isolates from mandarin as $P$ s. vitivorum, 11 isolates from walnut as Ps. juglandis. 78-100 \% strains of Ps. cerasi showed the sensitivity against antibiotics amoxicillin, ampicillin, moxifloxacin, ceftazidime and cefazolinom while none was resistant. However, $84 \%$ strains were resistant against cefoxitin, $46 \%$ and $56 \%$ strains- to azithromycin and cefuroxime, 40\% strains-to cefotaxime and cefalexinom, 20, 11 and 4\% strains accordingly-against antibiotics of ciprofloxacin, amikacin and ceftriaxon. No any strain sensitivity against cefoxitin was observed (Table 1).

The sensitivity of Ps. citri strains against antibiotics was alike with that of Ps. cerasi (Table 1). So that, 86-100\% strains indicated the sensitivity against the antibiotics of amoxicillin, ampicillin, moxifloxacin, ceftazidime and cefazolinom. No resistant strains against these antibiotics were observed.

Table1. Antibiotic sensitivity of strains of bacteria Ps. cerasi and Ps. citri

\begin{tabular}{|c|c|c|c|c|c|c|}
\hline \multirow{2}{*}{ Antibiotics } & \multicolumn{6}{|c|}{ Number of strains, \% } \\
\cline { 2 - 7 } & \multicolumn{3}{|c|}{ Ps.cerasi } & \multicolumn{3}{c|}{ Ps.citri } \\
\cline { 2 - 7 } & $\begin{array}{c}\text { Hyper } \\
\text { sensible }\end{array}$ & $\begin{array}{c}\text { Medium } \\
\text { sensible }\end{array}$ & Resistant & $\begin{array}{c}\text { Hyper } \\
\text { sensible }\end{array}$ & $\begin{array}{c}\text { Medium } \\
\text { sensible }\end{array}$ & Resistant \\
\hline Amikacin & 63 & 26 & 11 & 54 & 32 & 14 \\
\hline Amoxicillin & 100 & 0 & 0 & 94 & 6 & 0 \\
\hline Ampicillin & 98 & 2 & 0 & 96 & 4 & 0 \\
\hline Azithromycin & 32 & 22 & 46 & 38 & 21 & 41 \\
\hline Moxifloxacin & 100 & 0 & 0 & 100 & 0 & 0 \\
\hline Cefotaxime & 24 & 36 & 40 & 32 & 24 & 44 \\
\hline Ceftazidime & 94 & 6 & 0 & 88 & 12 & 0 \\
\hline Ceftriaxone & 82 & 14 & 4 & 77 & 18 & 5 \\
\hline Cefuroxime & 38 & 6 & 56 & 30 & 12 & 58 \\
\hline Cefazolinom & 78 & 22 & 0 & 86 & 14 & 0 \\
\hline Cefoxitin & 0 & 16 & 84 & 0 & 8 & 92 \\
\hline Ciprofloxacin & 48 & 32 & 20 & 51 & 30 & 19 \\
\hline Cefalexinom & 44 & 16 & 40 & 46 & 16 & 38 \\
\hline
\end{tabular}


Antibiotic Sensitivity of Some Phytopathogen Bacteria of Genus Pseudomonas Isolated from Fruit Trees of Azerbaijan

There were not resistant strains of Ps. juglandis species against the antibiotics of amoxicillin, ampicillin and cefazolinom. The strain with full sensitivity against

cefuroxime was not observed. $74 \%$ strains were resistant against these antibiotics. $56 \%$ strains indicated the resistance against the antibiotics of azithromycin, cefalexinom and moxifloxacin and 50$62 \%$ strains - against cefoxitin, ceftriaxone and cefotaxime. The amount of sensitive and resistant strains were equal against the antibiotics of amikacin and ceftazidime (Table 2).

Antibiotic sensitivity of the strains of Ps. piri is somewhat similar with those of Ps. cerasi and Ps. citri strains. So that, 88-100 \% strains have shown the sensitivity against the antibiotics of amoxicillin, ampicillin, moxifloxacin, ceftazidime and cefazolinom and there have not been any resistant strains against these antibiotics (Table 2). Nevertheless, according to correlations with antibiotics of cefotaxime, ceftriaxone, cefuroxime and cefoxitin the strains of this species have been different from strains of Ps. citri and Ps. cerasi species and 38-52\% of Ps. piri strains showed the sensitivity against these antibiotics.

78-100 \% strains of Ps. rubri showed the sensitivity against the antibiotics of amoxicillin, ampicillin, moxifloxacin, ceftazidime, ceftriaxone and cefazolinom andthere have not been any resistant strains against these antibiotics). The full- sensitive strains have not been observed against azithromycin antibiotic and the amount of resistant strains against this antibiotic was 70\%. 47-54\% strains were

Table2. Antibiotic sensitivity of strains of Ps. juglandis and Ps. piri

\begin{tabular}{|c|c|c|c|c|c|c|}
\hline \multirow{3}{*}{ Antibiotics } & \multicolumn{6}{|c|}{ Number of strains, $\%$} \\
\hline & \multicolumn{3}{|c|}{ Ps.juglandis } & \multicolumn{3}{|c|}{ Ps.piri } \\
\hline & $\begin{array}{c}\text { Hyper } \\
\text { sensible }\end{array}$ & $\begin{array}{l}\text { Medium } \\
\text { sensible }\end{array}$ & Resistant & $\begin{array}{c}\text { Hyper } \\
\text { sensible }\end{array}$ & $\begin{array}{l}\text { Medium } \\
\text { sensible }\end{array}$ & Resistant \\
\hline Amikacin & 43 & 12 & 45 & 45 & 42 & 13 \\
\hline Amoxicillin & 100 & 0 & 0 & 94 & 6 & 0 \\
\hline Ampicillin & 100 & 0 & 0 & 88 & 12 & 0 \\
\hline Azithromycin & 18 & 26 & 56 & 24 & 33 & 43 \\
\hline Moxifloxacin & 24 & 20 & 56 & 100 & 0 & 0 \\
\hline Cefotaxime & 22 & 16 & 62 & 52 & 16 & 32 \\
\hline Ceftazidime & 42 & 16 & 42 & 94 & 6 & 0 \\
\hline Ceftriaxone & 35 & 5 & 60 & 38 & 12 & 50 \\
\hline Cefuroxime & 0 & 26 & 74 & 52 & 6 & 42 \\
\hline Cefazolinom & 88 & 12 & 0 & 90 & 10 & 0 \\
\hline Cefoxitin & 28 & 38 & 50 & 49 & 21 & 30 \\
\hline Ciprofloxacin & 66 & 23 & 19 & 56 & 22 & 22 \\
\hline Cefalexinom & 21 & 24 & 56 & 44 & 22 & 34 \\
\hline
\end{tabular}

resistant against the antibiotics of cefoxitin, amikacin, cefotaxime and cefuroxime. The amount of sensitive and resistant strains was approximately the same against antibiotics of ciprofloxacin and cefalexinom (Table 3).

Table3. Antibiotic sensitivity of strains of bacteria Ps. rubri and Ps. vitivorum

\begin{tabular}{|c|c|c|c|c|c|c|}
\hline \multirow{3}{*}{ Antibiotics } & \multicolumn{6}{|c|}{ Number of strains, \% } \\
\hline & \multicolumn{3}{|c|}{ Ps.rubri } & \multicolumn{3}{|c|}{ Ps.vitivorum } \\
\hline & $\begin{array}{c}\text { Hyper } \\
\text { sensible }\end{array}$ & $\begin{array}{l}\text { Medium } \\
\text { sensible }\end{array}$ & Resistant & $\begin{array}{c}\text { Hyper } \\
\text { sensible }\end{array}$ & $\begin{array}{l}\text { Medium } \\
\text { sensible }\end{array}$ & Resistant \\
\hline Amikacin & 23 & 28 & 49 & 57 & 43 & 0 \\
\hline Amoxicillin & 96 & 4 & 0 & 90 & 10 & 0 \\
\hline Ampicillin & 100 & 0 & 0 & 95 & 5 & 0 \\
\hline Azithromycin & 0 & 30 & 70 & 32 & 34 & 34 \\
\hline Moxifloxacin & 96 & 4 & 0 & 98 & 2 & 0 \\
\hline Cefotaxime & 22 & 24 & 54 & 48 & 6 & 46 \\
\hline Ceftazidime & 88 & 12 & 0 & 58 & 42 & 0 \\
\hline Cefrtiaxone & 80 & 20 & 0 & 56 & 6 & 38 \\
\hline Cefuroxime & 38 & 8 & 54 & 46 & 3 & 51 \\
\hline Cefazolinom & 78 & 22 & 0 & 82 & 18 & 0 \\
\hline Cefoxitin & 27 & 26 & 47 & 21 & 30 & 49 \\
\hline Ciprofloxacin & 44 & 23 & 43 & 60 & 23 & 17 \\
\hline Cefalexinom & 38 & 26 & 36 & 43 & 12 & 45 \\
\hline
\end{tabular}


57-98\% strains of Ps. vitivorum showed the sensitivity against the antibiotics of amikacin, amoxicillin, ampicillin, ceftazidime, cefazolinom and moxifloxacin and there have not been any resistant strains against these antibiotics. The number of the sensitive and resistant strains against the antibiotics of azithromycin, cefotaxime, cefuroxime and cefalexinom was very close. $51 \%$ and $49 \%$ strains were resistant accordingly against cefuroxime and cefoxitin antibiotics.

\section{CONCLUSION}

So, it was determined that all the investigated bacterial strains showed high sensitivity against amoxicillin, ampicillin and cefazolinom antibiotics and resisitant strains were not observed against these antibiotics. All the strains of Ps. cerasi, Ps.citri, Ps. piri, Ps. rubri and Ps. vitivorum species demonstrated the hypersensitivity against moxifloxacin and ceftazidime antibiotics. At the same time, the strains of Ps. rubri demonsrated the hypersensitivity to ceftriaxone antibiotic and the strains of $P S$. vitivorum did the same to amikacin antibiotic and their resistant srtains to these antibiotics were not observed. There were high resistant strains of Ps. cerasi and Ps. citri to cefoxitin antibiotic, Ps. juglandis - to cefuroxime antibiotic and Ps. rubri - to azithromycin antibiotic.

\section{REFERENCES}

[1] Balouiri M., Sadiki M. and Ibnsouda S. Methods for in vitro evaluating antimicrobial activiti: A review. J. Pharmaceutical Analysis. 6(2),71-79(2016).

[2] Brenner D., Krieg N. and Staley J. Bergey's Manual of Systematic Bacteriology. 2:323-378. Spinger.New York.USA (2005).

[3] Burgovich G.K. 2007. Phytopathogen Bacteria. Publisher name, Moscow: Nauka, 252p.(2007)(in Russian).

[4] Islam M.A., Mazumdar R.M., Islam S., Adam M.J. and Urmee S.A. Isolation, identification and in-vitro antibiotic sensitivity pattern of citrus canker causing organism Xanthomonas axonopodis. Advancements in Life Sciences. 1(4), 215-222 (2014).

[5] Karimova Y.V., Aleksandrov I.N, and Shkeyder EY. 2012. Causative agent of bacterioses of plants. Zashita i karantin rasteniy. 12,1-6, (2012) (in Russian).

[6] Kotlyarov V. and Kotlyarov D. Control pathogenicity of Pseudomonas syringae spp. by disorganization of their community and increasing of plant metabolism.pp40. In: Book abstract of 8-th Inter. Confer. Oxford.U.K.(2010).

[7] Mudgett M.B. New insights to the function of phytopathogenic bacterial type. Ann. Rev. Plant. Biol. 56, 509-531 (2015).

[8] Valiyeva F.T. and Ganbarov Kh.G. Influence of antibiotics on the growth of phytopathogen bacteria. Transaction of the institute of microbiology ofAzerbaijan National Academy of sciences. Baku-Elm 14(1), 92-98 (2016).

[9] Valiyeva F.T and Ganbarov Kh.G. Antibiotic sensitivity of phytopathogen bacteria genus of Pseudomonas. Agrarion science 4,84-87 (2016).

[10] Van Bodman S.B, Baur W.D, Coplin D.L. Quorum sensing in plant- pathogenic. Ann. Rev. Phytopathol. 41,455-482 (2003).

[11] Yakovlev L.M., Patika V.F., Gvozyak R.I. and Sherbina T.N. Phytopathogen bakteria of wheat. Mikrobiologicheskiy journal 71(3), 30-37(2009).

Citation: K. Ganbarov et al., "Antibiotic Sensitivity of Some Phytopathogen Bacteria of Genus Pseudomonas Isolated from Fruit Trees of Azerbaijan", International Journal of Research Studies in Biosciences (IJRSB), vol. 6, no. 1, pp. 6-9, 2018. http://dx.doi.org/10.20431/2349-0365.0601002

Copyright: () 2018 Authors. This is an open-access article distributed under the terms of the Creative Commons Attribution License, which permits unrestricted use, distribution, and reproduction in any medium, provided the original author and source are credited. 